\title{
Standardization of Propagation Technique and Media Combination in Acid Lime (Citrus aurantifolia) var. PKM 1
}

\author{
V. Sabari Priya ${ }^{1 *}$, C. Subesh Ranjith Kumar ${ }^{1}$, R. Poorniammal', \\ J. Rajangam ${ }^{1}$ and K. Venkatesan ${ }^{3}$
}

\author{
${ }^{1}$ Dept of Fruit Science, Horticultural College and Research Institute, Periyakulam, India \\ ${ }^{2}$ Dept of Natural Resource Management, Horticultural College and Research Institute, TNAU, \\ Periyakulam, India \\ ${ }^{3}$ Dept of Floriculture and Landscape Architecture, Horticultural College and Research \\ Institute, TNAU, Periyakulam, India
}

*Corresponding author

\begin{abstract}
A B S T R A C T
Plant Growth Promoting Rhizobacteria (PGPR) is considered responsible for influencing plant growth by natural means. Understanding the role of PGR and

\section{Keywords}

Acid lime, Cuttings, Indole-3-Acetic Acid, PGPR, Substrate

\section{Article Info}

Accepted:

17 September 2020

Available Online:

10 October 2020 PGPR in increasing the rooting ability of the cuttings, the isolated cultures of PGPR with better performance in comparison with PGR based combination were used for the present study and made as combination in media with different propositions. On comparison with IBA, PGPR based microbial strain had significantly greater rooting ability. Growth performance of acid lime cuttings had showed that the root length, shoot length and number of roots per plant were maximum in $\mathrm{M}_{2} \mathrm{~S}_{5}$ of medium cuttings from microbial strain II of Bacillus spp. @ 2 per cent (IAA) at 90 DAP and the survival percentage was maximum in $\mathrm{M}_{1} \mathrm{~S}_{5}$ of terminal cutting from microbial strains of Bacillus spp. @ 2 per cent (IAA) at 90 DAP. The study revealed that the medium cuttings treated with Microbial strain II @ 2 per cent media combination has given better result over the control which has greater advantage in nursery production of quality seedling, in a short span of time which is considered to be a challenging task.
\end{abstract}

\section{Introduction}

Acid lime is an important commercial fruit crop grown throughout the world. India ranks fifth among the major lime or lemon producing countries in the world
(Horticultural Statistics at a glance, 2018). Acid lime is the native of India and it is largest producer in the world. Tamil Nadu has an immense potential in growing acid lime and major acid lime growing regions are the Districts of Dindigul, Perambalur, Theni, 
Tenkasi, Tirunelveli, Thoothukudi, Sivagangai and Virudhunagar.

Cutting is a well known common and relatively cheap method used in the propagation of many plant species. Acid lime is regenerated through seeds, the high chance of viral disease contamination and non uniformity of progeny is a major problem by the method (Babu, 2001). The stem cutting is suitable method for regeneration of acid lime because it has high intensity of Polyembryony (90 per cent) and least chance of viral disease contamination. Synthetic compounds that act like natural plant hormones are called Plant Growth Regulators (Davies, 1995). Plant Growth Regulators are naturally produced chemicals to regulate the growth and development. Plants produce natural auxins such as Indole -3-Acetic Acid (IAA) and Indole Butyric Acid (IBA) and Plant Growth Promoting Rhizobacteria (PGPR) are both considered responsible for influencing the plant growth (Farah et al., 2005).

Indole Acetic Acid is one of the most physiologically active auxin and it is a common product of L- Tryptophan metabolism produced by microorganisms including PGPR (Lynch, 1985). Indole Acetic Acid helps in the production of longer roots with increased number of lateral roots and root hairs (Datta and Basu, 2000). The idea of the work is to integrate the promising strain of PGPR with the media combination used for earlier and quick rooting. Likewise, choice of cuttings with pencil thickness from the terminal, medium and basal portion were taken up for the study in generating the roots when treated with media combination.

Also an attempt to increase the rooting habit of the cuttings by utilising the PGPR by isolating the strains from the soil sample taken up from different acid lime growing regions of Tamil Nadu. However, the propagation through cuttings are so promising it is understood from previous scientific outputs and nursery practical experiences, quality planting material through cuttings takes more time. Hence the study aims at developing a standardizing suitable propagation technique with respect to cutting choice and media combination in enhancing the rooting at the earliest.

\section{Materials and Methods}

\section{Isolation and purification of bacteria}

The total microbial counts in terms of colony forming units (CFU) of bacteria, fungal and actinomycetes in the soil sample rhizosphere were determined using standard plate count method (Nagarathinam et al., 2000). From the total colony forming units of bacterial colonies which showed predominant growth were re-streaked on to appropriate agar medium to obtain pure cultures and subjected to characterization and identification (Table $1)$.

\section{In vitro indolic compounds production by bacteria}

Screening of bacterial strains for production of plant growth regulator (IAA)

All the bacterial strains were screened for the production of Indole-3-acetic acid (IAA). The strains were separately inoculated in the nutrient broth medium with tryptophan (1 $\mathrm{mg} / \mathrm{ml}$ ) or without tryptophan and incubated at $28 \pm 2^{\circ} \mathrm{C}$ for one week. After a week the cultures were centrifuged at $3000 \mathrm{rpm}$ for 30 min. Two millilitres of the supernatant was mixed with two drops of orthophosphoric acid and $4 \mathrm{ml}$ of Salkowski's reagent $(50 \mathrm{ml}$ of 35 per cent Perchloric acid $+1 \mathrm{ml}$ of $0.5 \mathrm{FeCl}_{3}$ ). Development of a pink colour indicates IAA production. OD was read at $530 \mathrm{~nm}$ by using Spectrophotometer. The level of IAA 
produced was estimated by a standard IAA graph (Loper and Schroth, 1986). Among the colonies tested, best colonies which are able to produce higher concentration of IAA was screened and from that only two colonies produced a higher rate of IAA compared to others were used for the study. The idea of screening for the high IAA producing strain was to bring its inherent ability in generating more roots during the study.

\section{Extraction of crude IAA}

Bacterial colonies of 1 isolate of Bacillus spp. and 1 strain of Bacillus spp. were inoculated in $200 \mathrm{ml}$ of nutrient broth amended with 1 $\mathrm{mg} / \mathrm{ml}$ of tryptophan and incubated at $28 \pm$ $2^{\circ} \mathrm{C}$ for 1 week on a shaker incubator. Bacterial cells were separated from the supernatant by centrifugation at $10,000 \mathrm{rpm}$ for $30 \mathrm{~min}$. The supernatant was acidified to $\mathrm{pH} 2.5$ to 3.0 with $1 \mathrm{~N} \mathrm{HCl}$ and extracted twice with ethyl acetate at double the volume of the supernatant. Extracted ethyl acetate fraction was evaporated to dryness in a rotator evaporator at $40{ }^{\circ} \mathrm{C}$. The prepared microbial strains I and II of 1 per cent and 2 per cent was to be treated with cuttings in a framed media combination.

\section{In vivo experiment of plant promotion by native PGP isolates}

The experiment was laid out in Factorial Completely Randomized Design (FCRD) with three replication and 25 cuttings per replication and the treatment details and combinations are given below.

Variety - PKM-1 acid lime

Growing condition - Mist chamber with $80 \%$ $\mathrm{RH}$

Number of factors -2

Number of treatment combinations - Fifteen

Number of Replications - Three

Number of Cuttings per replication - Twenty five

\section{Factor 1: Method of cuttings}

$\mathrm{M}_{1}$ - Terminal cutting

$\mathrm{M}_{2}-$ Medium cutting

$\mathrm{M}_{3}-$ Basal cutting

\section{Factor 2 : Effect of Substrates}

$\mathrm{S}_{1}-$ Red soil + Sand + Organic manure $(2: 1: 1)+$ IBA $2000 \mathrm{ppm}$

$\mathrm{S}_{2}-$ Red soil + Sand + Organic manure $(2: 1: 1)+$ M.S I @ 1 per cent

$\mathrm{S}_{3}-\mathrm{Red}$ soil + Sand + Organic manure (2:1:1)+ M.S I @ 2 per cent

$\mathrm{S}_{4}-$ Red soil + Sand + Organic manure $(2: 1: 1)+$ M.S II @ 1 per cent

$\mathrm{S}_{5}-$ Red soil + Sand + Organic manure $(2: 1: 1)+$ M.S II @ 2 per cent

\section{Treatment combination}

\begin{tabular}{|c|c|c|c|}
\hline $\mathbf{M} \times \mathbf{S}$ & $\mathbf{M}_{\mathbf{1}}$ & $\mathbf{M}_{2}$ & $\mathbf{M}_{\mathbf{3}}$ \\
\hline $\mathbf{S}_{\mathbf{1}}$ & $\mathrm{M}_{1} \mathrm{~S}_{1}$ & $\mathrm{M}_{2} \mathrm{~S}_{1}$ & $\mathrm{M}_{3} \mathrm{~S}_{1}$ \\
\hline $\mathbf{S}_{\mathbf{2}}$ & $\mathrm{M}_{1} \mathrm{~S}_{2}$ & $\mathrm{M}_{2} \mathrm{~S}_{2}$ & $\mathrm{M}_{3} \mathrm{~S}_{2}$ \\
\hline $\mathbf{S}_{\mathbf{3}}$ & $\mathrm{M}_{1} \mathrm{~S}_{3}$ & $\mathrm{M}_{2} \mathrm{~S}_{3}$ & $\mathrm{M}_{3} \mathrm{~S}_{3}$ \\
\hline $\mathbf{S}_{\mathbf{4}}$ & $\mathrm{M}_{1} \mathrm{~S}_{4}$ & $\mathrm{M}_{2} \mathrm{~S}_{4}$ & $\mathrm{M}_{3} \mathrm{~S}_{4}$ \\
\hline $\mathbf{S}_{\mathbf{5}}$ & $\mathrm{M}_{1} \mathrm{~S}_{5}$ & $\mathrm{M}_{2} \mathrm{~S}_{5}$ & $\mathrm{M}_{3} \mathrm{~S}_{5}$ \\
\hline
\end{tabular}

In the treatment combination, method of cuttings such as terminal, medium and basal cuttings has to dipped with effect of substrates IBA@ 2000 ppm, M.S I and M.S II at 1 per cent and 2 per cent. Five cuttings in each replication were randomly selected and tagged for recording morphological and biochemical observation in the nursery.

The experiment was taken up in the mist chamber maintained at the Central Farm Nursery in the Department of Fruit Science, Horticultural College and Research Institute, TNAU, Periyakulam, Theni. 


\section{Statistical analysis}

The experimental design used was a Factorial Completely Randomized block with 2 factors and 3 replications. Each replication contained 25 cuttings. Data were subjected to analysis of variance using ANOVA and means were separated by Duncan's multiple range tests $(\mathrm{p}<0.05)$. The data recorded were subjected to statistical analysis as per the method suggested by Panse and Sukhatme (1995).

\section{Results and Discussion}

Enumeration of microbial population in the Acid lime rhizospher

The total microbial population were assessed in the collected acid lime rhizosphere acress tamilnadu. Among the soil samples, highest bacterial count was recorded $\left(94 \times 10^{-6} \mathrm{CFU}\right)$ in the soil sample collection of Acid lime 7 rhizosphere of Tenkasi District followed by Acid lime 6 of Madurai District $\left(92 \times 10^{-6}\right.$ $\mathrm{CFU})$ and the lowest bacterial count was observed (35 x $\left.10^{-6} \mathrm{CFU}\right)$ in the soil sample collection of Acid lime 1 rhizosphere of Theni District.. Among the fungal and actinomycetes count of the soil sample, highest fungal count was recorded $\left(28 \times 10^{-3}\right.$ $\mathrm{CFU}$ ) in the soil sample collection of Acid lime 10 rhizosphere of Trichy District and the highest actinomycetes count was observed (18 $x 10^{-4} \mathrm{CFU}$ ) in the soil sample collection of Acid lime 13 rhizosphere of Dindigul District (Table 2).

\section{In vitro indolic compounds production}

On a comparative basis, isolate from soil sample collection of Acid lime 7 rhizosphere was recorded the highest production of IAA $(1.94 \mathrm{mg} / \mathrm{ml})$ and the lowest production of IAA $(0.41 \mathrm{mg} / \mathrm{ml})$ was observed from the soil sample collection of Acid lime 5 rhizosphere of Kanyakumari District in the presence of
$1 \mathrm{mg} / \mathrm{ml}$ of tryptophan for promoting plant growth. On the other hand, the result showed that bacterial isolates from soil sample collection of Acid lime 7 rhizosphere was observed the highest production of IAA (1.23 $\mathrm{mg} / \mathrm{ml}$ ) and the bacterial isolates from soil sample collection Acid lime 1 rhizosphere of Theni District was recorded the lowest production of IAA $(0.08 \mathrm{mg} / \mathrm{ml})$ in the absence of tryptophan (Table 3 ).

\section{Effect of PGPR on induction of Shoot and root growth of Acid lime stem cuttings}

PGPR can exhibit a variety of characteristics responsible for influencing plant growth. The common traits include production of plant growth regulators (Auxin, Gibberellin, Ethylene etc.), siderophores, HCN and antibiotics. Indole acetic acid (IAA) is one of the most physiologically active auxins. IAA is a common product of L-tryptophan metabolism by several microorganisms including PGPR.

Root length was recorded highest in medium cuttings treated with M.S II at 2 per cent $\left(\mathrm{M}_{2} \mathrm{~S}_{5}\right)$ which was about $17.03 \mathrm{~cm}$ at 30 DAP, $\left(\mathrm{M}_{2} \mathrm{~S}_{1}\right)$ of medium cuttings treated with IBA @ $2000 \mathrm{ppm}$ which was about $26.83 \mathrm{~cm}$ at 60 DAP and $\left(\mathrm{M}_{2} \mathrm{~S}_{5}\right)$ of medium cutting treated with M.S II at 2 per cent was observed 27.29 $\mathrm{cm}$ highest at 90 DAP.

Highest number of roots per plant was recorded in the treatment combination of medium cutting treated with M.S II at 1 per cent $\left(\mathrm{M}_{2} \mathrm{~S}_{4}\right)$ which was about 12.00 at 30 DAP and $\left(\mathrm{M}_{2} \mathrm{~S}_{5}\right)$ of medium cutting treated with M.S II at 2 per cent which was about 12.66 and 13.67 at 60 and 90 DAP respectively.

Survival percentage was recorded highest in the treatment combination of medium cutting treated with M.S II at 2 per cent $\left(\mathrm{M}_{2} \mathrm{~S}_{5}\right)$ which 
was about 94.66 per cent at $30 \mathrm{DAP},\left(\mathrm{M}_{2} \mathrm{~S}_{1}\right)$ of medium cuttings treated with IBA at 2000 ppm which was about 94.33 per cent at 60
DAP and $\left(\mathrm{M}_{2} \mathrm{~S}_{5}\right)$ of medium cuttings treated with M.S II at 2 per cent which was about 93.33 per cent at 90 DAP.

Table.1 Details of soil sample taken on acid lime growing regions of Tamil Nadu

\begin{tabular}{|c|l|l|}
\hline S.No & \multicolumn{1}{|c|}{ Soil sample collection } & \multicolumn{1}{|c|}{ District } \\
\hline $\mathbf{1}$ & Periyakulam & Theni \\
\hline $\mathbf{2}$ & MelaneelithaNallur & Tirunelveli \\
\hline $\mathbf{3}$ & Kadayam & Tirunelveli \\
\hline $\mathbf{4}$ & Thevarkulam & Virudhunagar \\
\hline $\mathbf{5}$ & Santhapuram & Kanyakumari \\
\hline $\mathbf{6}$ & Melapuliyankulam & Madurai \\
\hline $\mathbf{7}$ & Tenkasi & Tenkasi \\
\hline $\mathbf{8}$ & Vannikonaendhal & Tirunelveli \\
\hline $\mathbf{9}$ & Nasiyanur & Erode \\
\hline $\mathbf{1 0}$ & Trichy & Trichy \\
\hline $\mathbf{1 1}$ & Usalampatti & Madurai \\
\hline $\mathbf{1 2}$ & Theni & Theni \\
\hline $\mathbf{1 3}$ & Nilakottai & Dindigul \\
\hline
\end{tabular}

Table.2 Enumeration of microbial population in the Acid lime rhizosphere

\begin{tabular}{|c|c|c|c|c|}
\hline S.NO & Sample & Bacteria X $\mathbf{~ 1 0}^{-6}$ & Fungi X 10 & Actinomycetes X $\mathbf{~ 1 0}^{-\mathbf{4}}$ \\
\hline $\mathbf{1}$ & Acid lime 1 & 76 & 23 & 13 \\
\hline $\mathbf{2}$ & Acid lime 2 & 84 & 20 & 8 \\
\hline $\mathbf{3}$ & Acid lime 3 & 78 & 25 & 15 \\
\hline $\mathbf{4}$ & Acid lime 4 & 90 & 18 & 6 \\
\hline $\mathbf{5}$ & Acid lime 5 & 48 & 14 & 10 \\
\hline $\mathbf{6}$ & Acid lime 6 & 92 & 22 & 8 \\
\hline $\mathbf{7}$ & Acid lime 7 & 94 & 16 & 13 \\
\hline $\mathbf{8}$ & Acid lime 8 & 82 & 26 & 15 \\
\hline $\mathbf{9}$ & Acid lime 9 & 79 & 17 & 13 \\
\hline $\mathbf{1 0}$ & Acid lime 10 & 59 & 28 & 11 \\
\hline $\mathbf{1 1}$ & Acid lime 11 & 76 & 23 & 18 \\
\hline $\mathbf{1 2}$ & Acid lime 12 & 64 & 22 & \\
\hline $\mathbf{1 3}$ & Acid lime 13 & 87 & 25 & \\
\hline
\end{tabular}


Table.3 Screening of bacterial strains for production of IAA on Rhizosphere Acid lime rhizopshere

\begin{tabular}{|c|c|c|c|}
\hline S.No. & Sample & $\begin{array}{c}\text { With Tryprtophan } \\
\text { (1mg/100g) }\end{array}$ & Without Tryptophan \\
\hline $\mathbf{1}$ & Acid lime 1 & 0.76 & 0.18 \\
\hline $\mathbf{2}$ & Acid lime 2 & 0.88 & 0.62 \\
\hline $\mathbf{3}$ & Acid lime 3 & 0.79 & 0.68 \\
\hline $\mathbf{4}$ & Acid lime 4 & 1.00 & 0.81 \\
\hline $\mathbf{5}$ & Acid lime 5 & 0.41 & 0.25 \\
\hline $\mathbf{6}$ & Acid lime 6 & 1.71 & 0.91 \\
\hline $\mathbf{7}$ & Acid lime 7 & 1.94 & 1.23 \\
\hline $\mathbf{8}$ & Acid lime 8 & 1.03 & 0.93 \\
\hline $\mathbf{9}$ & Acid lime 9 & 1.15 & 0.91 \\
\hline $\mathbf{1 0}$ & Acid lime 10 & 0.79 & 0.54 \\
\hline $\mathbf{1 1}$ & Acid lime 11 & 1.04 & 0.89 \\
\hline $\mathbf{1 2}$ & Acid lime 12 & 0.82 & 0.51 \\
\hline $\mathbf{1 3}$ & Acid lime 13 & 1.23 & 0.84 \\
\hline
\end{tabular}

*Acid lime 1-Periyakulam, 2-MelaneelithaNallur, 3-Kadayam, 4-Thevarkulam, 5-Santhapuram, 6Melapuliyankulam, 7-Tenkasi, 8-Vannikonaendhal, 9-Nasiyanur, 10-Trichy, 11-Usalampatti, 12-Theni, 13Nilakottai

Figure.1 Effect of method of cuttings in the performance of acid lime for root length at 90 DAP

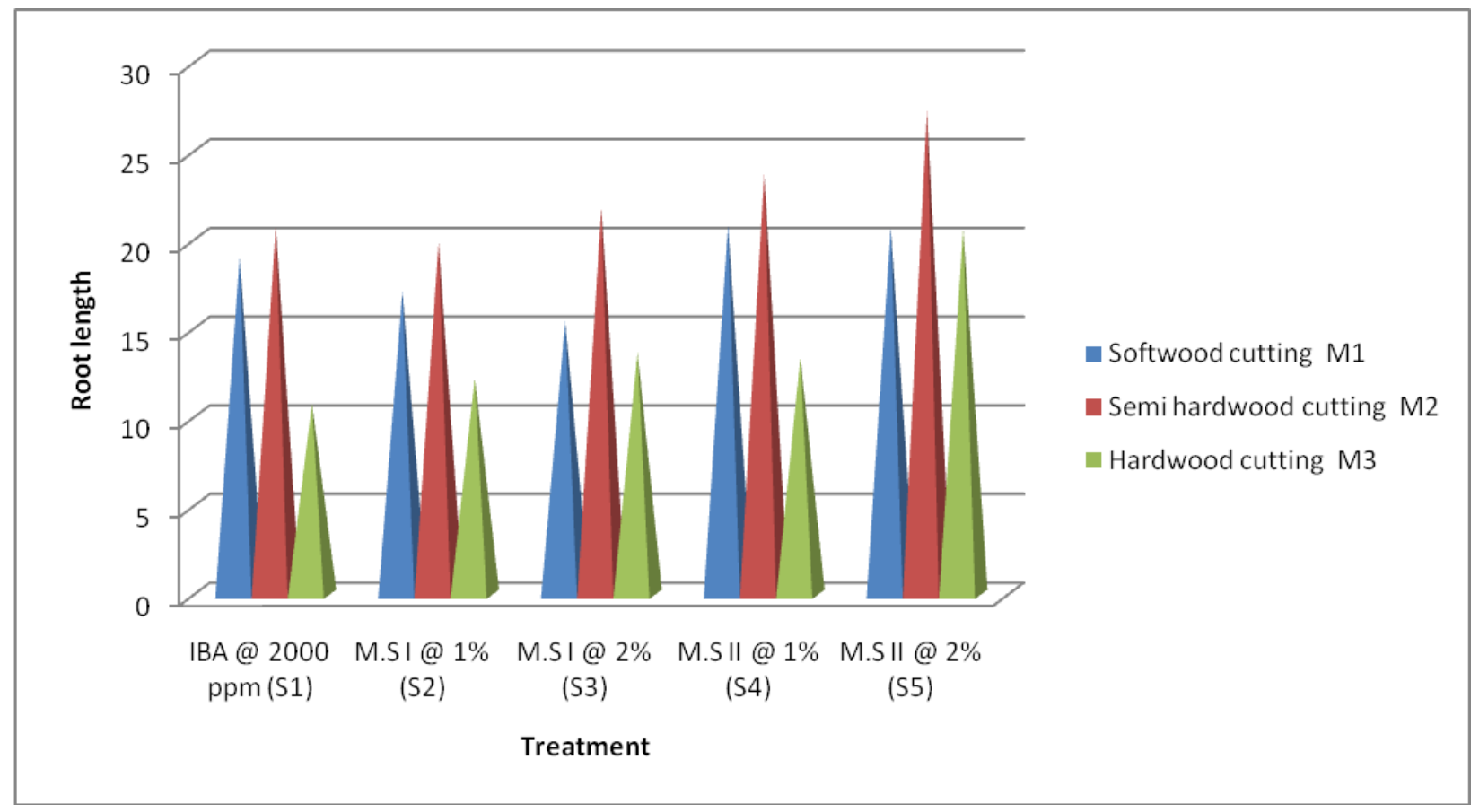


Figure.2 Effect of method of cuttings in the performance of acid lime for Number of roots per plant at 90 DAP

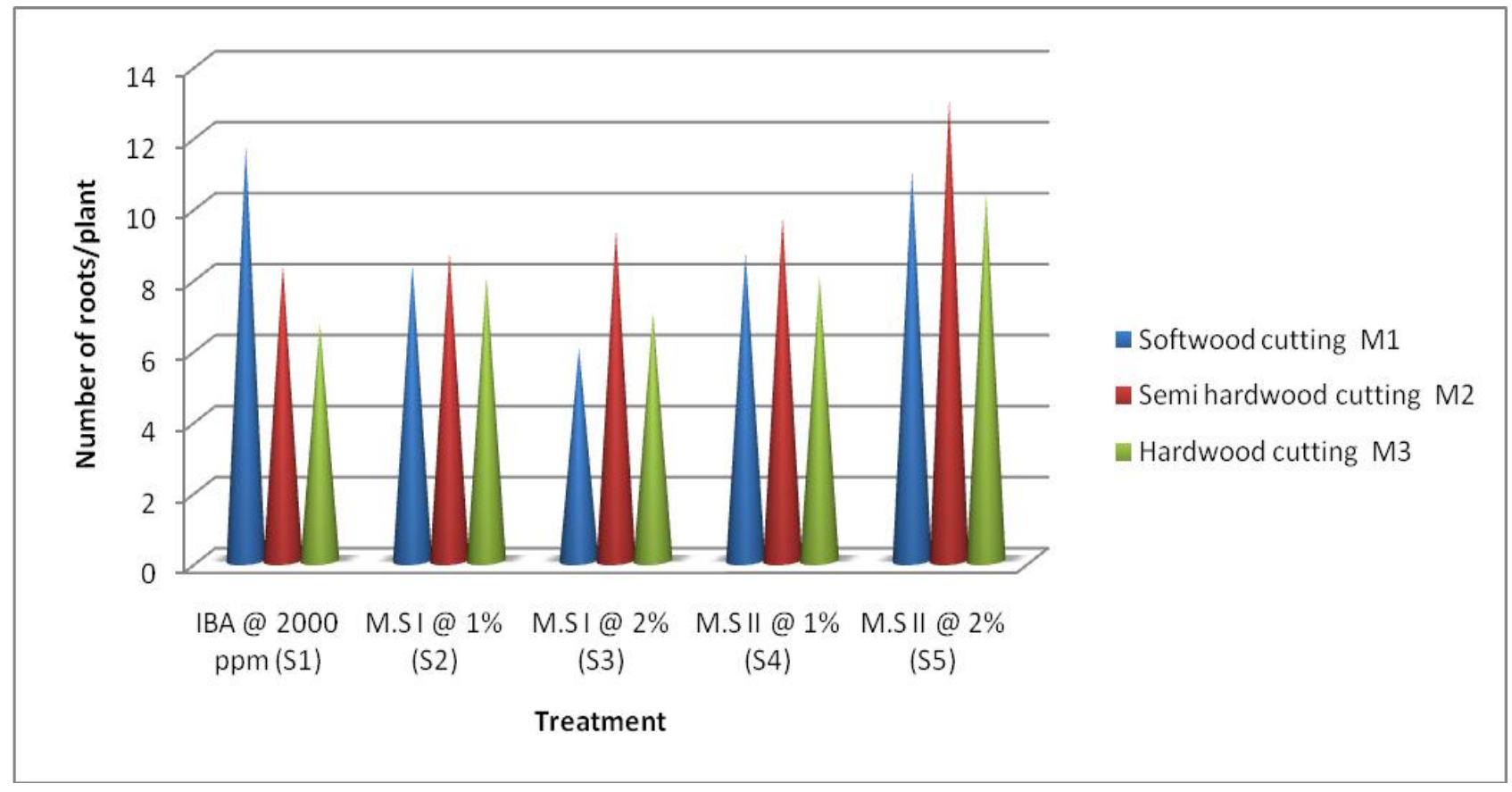

Figure.3 Effect of method of cuttings in the performance of acid lime for survival percentage at 90 DAP

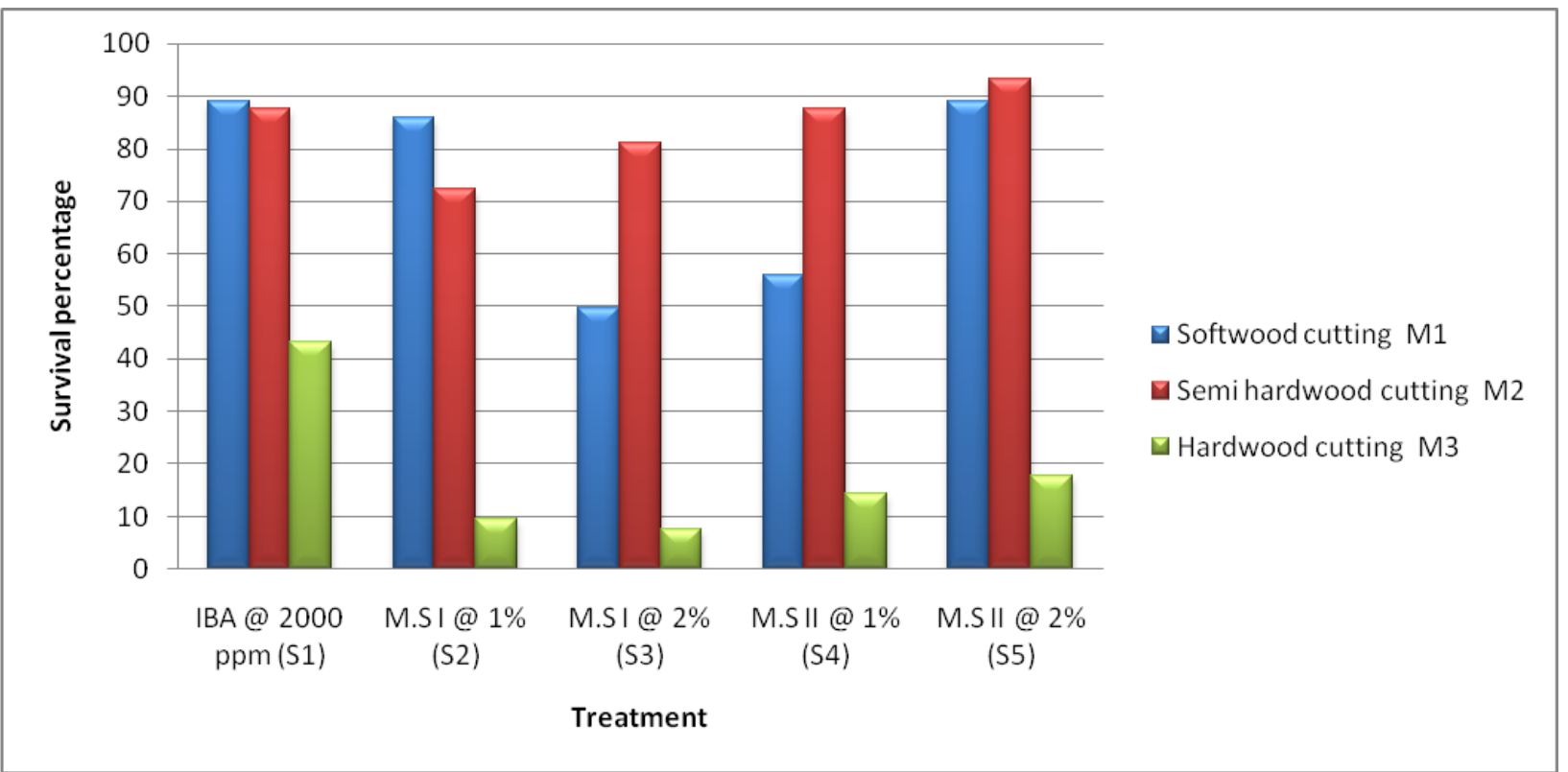


Figure.4 Effect of method of cuttings in the performance of acid lime for shoot length at 90 DAP

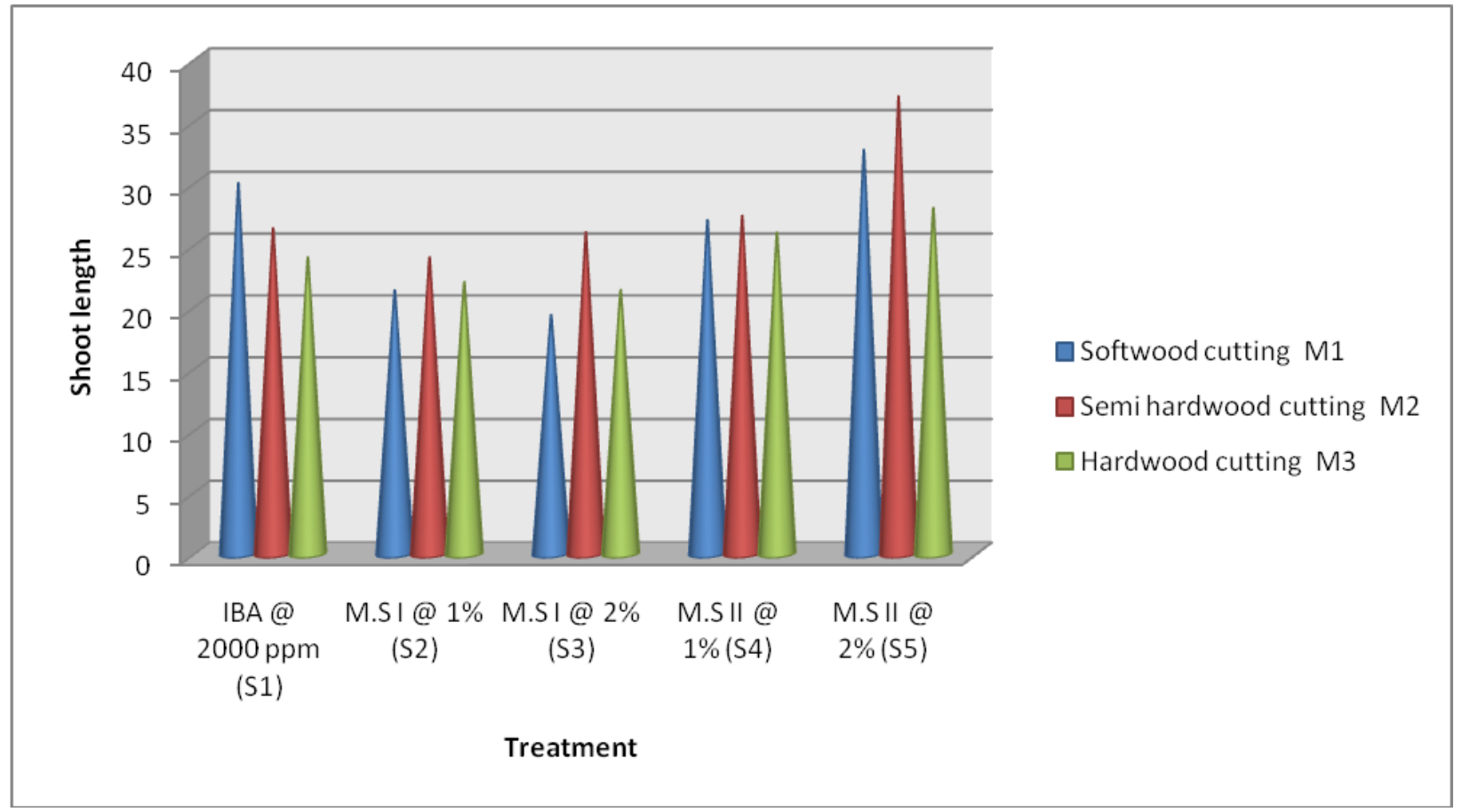

Figure.5 Effect of method of cuttings in the performance of acid lime for Number of shoots per plant at 90 DAP

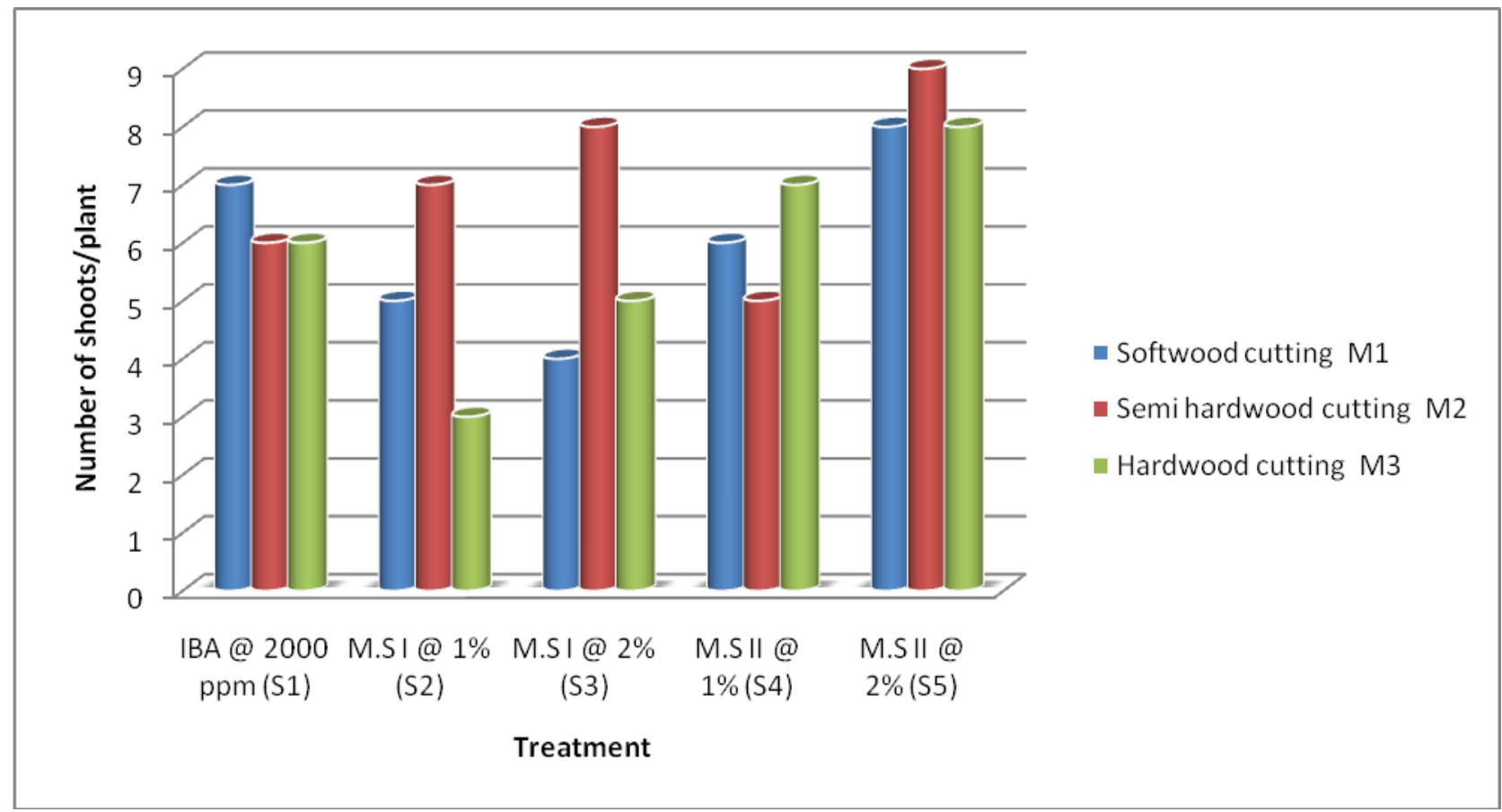

Shoot length was recorded highest in the treatment of medium cuttings treated with
M.S II at 2 per cent $\left(\mathrm{M}_{2} \mathrm{~S}_{5}\right)$ which was about $30.33 \mathrm{~cm}$ at 30 DAP, $\left(\mathrm{M}_{2} \mathrm{~S}_{1}\right)$ of medium 
cuttings treated with IBA at 2000 ppm which was about $35.33 \mathrm{~cm}$ at $60 \mathrm{DAP}$ and $\left(\mathrm{M}_{2} \mathrm{~S}_{5}\right)$ of medium cuttings treated with M.S II at 2 per cent which was about $37.00 \mathrm{~cm}$ at 90 DAP. Highest number of shoots/plant was observed in the treatment combination of medium cuttings treated with M.S II at 2 per cent $\left(\mathrm{M}_{2} \mathrm{~S}_{5}\right)$ which was about 8 at 30 DAP, $\left(\mathrm{M}_{2} \mathrm{~S}_{1}\right)$ of medium cuttings treated with IBA at 2000 ppm which was about 9 at 60 DAP and $\left(\mathrm{M}_{2} \mathrm{~S}_{5}\right)$ of medium cuttings treated with M.S II at 2 per cent which was about 9 at 90 DAP.

Among the treatment combination, concentration of Microbial strain II at 2 per cent performed the best. This might be due to the reason that auxin activated shoot growth could have elongated the stems and leaves through cell division accounting for a higher dry weight of shoot (Abraham, 1996). The promoting effect of IBA on shoot parameters can be attributed to the reason that the better rooting coupled with a better leaf growth might have led to a higher shoot sprouts and supported their development (Paul and Aditi, 2009). The integrated effect over root and shoot parameters established the concentration of IBA at 2000 ppm and Plant Growth Promoting Rhizobacteria.

IBA helps in mobilizing reserved food material, elongation of meristematic cells and differentiation of cambial initials into root primordial. Rana and Jindal (2001) also observed that increase in root length and diameter with auxin treatment. Alam et al., (2007) reported that IBA promote cell elongation which helped in increased root length. Also, increase in root diameter may be due to more vegetative growth and accumulation of carbohydrates. These results are in conformity with Rathore (1984) who also reported that in kiwifruit application of IBA leads to increase in length and diameter of roots. The increase in root mass is due to more number and length of roots. Successful rooting of cuttings is determined both by the number of roots formed, root elongation and growth Hartmann et al., (1990).

Increases in rooting percentage and root growth of cuttings varied according to PGPR were tested. All PGPR increased root growth and rooting percentage over the control. These results show that the PGPR treatment was useful for root induction in acid lime stem cuttings. Auxin production by bacteria is one of the explanation of root induction in kiwifruit stem cuttings.

Many microorganisms that interact with plants can synthesize hormones similar to those produced by the plant as growth regulator, such as auxins, gibberellins and cytokines. Among them, auxin is one of the most well-known phytohormones because of its important role in the initial processes of lateral and adventitious root formation and root elongation. Our results showed that PGPR produce auxin themselves and may also affect auxin synthesis of cuttings. IAA is the most commonly produced auxin in nature, synthesized mainly through tryptophan dependent pathways. The endogenous level of IAA in the plant is also important for successful rooting.

It is evident that the treatment of PGPR on cuttings of different plant species showed genotype dependent rooting and increased root growth. Patten and Glick (2002) reported that IAA producing Pseudomonas putida increased the length of canola seedling roots on average 35 to 50 per cent. Bae et al., (2007) stimulated initial development of adventitious roots in cucumber and rose cuttings, using different PGPR isolates. Ercisli et al., (2004) and Esitken et al., (2003) tested PGPR for rooting in rose hip and sour cherry cuttings and found that PGPR were effective to obtain high rooting percentages. Caesar and Burn observed that seedlings of 
apple gave better lateral roots when treated with PGPR. Kaymak et al., (2008) also demonstrated that mint cuttings inoculated with PGPR resulted in higher rooting percentage and root dry weight (Fig. 1-5).

From the present study it is concluded that the medium cuttings of acid lime treated with M.S II @ 2 Per cent planted in polyethylene bags containing Red Soil + Sand + Organic manure in $(2: 1: 1)$ proportion was found to be the best treatment for induction of rooting, maximum survival percentage (93.33\%), maximum shoot length $(37.00 \mathrm{~cm})$, number of shoots (9.00), maximum root length (27.29 $\mathrm{cm})$ and number of roots (13.67) per cutting at the end of 90 DAP.

It is concluded that the present study on "Standardization of propagation technique and media combination in acid lime (Citrus aurantifolia) var. PKM 1" demonstrated that the PGPR belonging to genus Bacillus spp. has potential to promote root formation in acid lime cuttings in mass clonal propagation. It seems that the stimulation of rooting and root growth by PGPR can be correlated to production of indole-3-acetic acid by the bacteria. In our study, the PGPR has higher IAA producing capacity, which also resulted in higher rooting percentage in cuttings. As well-known, the use of chemicals in plant propagation can produce environmental problems and may increase the cost of propagation in nurseries. Among the treatment combination in the method of cuttings, medium cuttings should produce profuse rooting and more number of branches compared with basal and terminal cuttings. In the terms of effect of substrate, application of PGPR Microbial strain II at 2 Per cent was superior and gave more roots compared to other treatment IBA and Microbial strain I. From the study it is concluded that the medium cuttings of acid lime treated with M.S II @ 2 Per cent planted in polyethylene bags containing Red Soil + Sand + Organic manure in $(2: 1: 1)$ proportion was found to be the best treatment and are also more effective on rooting and maximize the yield of acid lime cuttings in nursery propagation. Therefore, these results can also be important for the use of these PGPR to multiply organic nursery materials. In fact, several commercial PGPR products are already being used in organic agriculture practice.

\section{References}

Alam, R., Rahman, K. U., Ilyas, M., Ibrahim, M., Rauf, M. A. (2007). Effect of Indole Butyric acid concentrations on the rotting of Kiwi cuttings. Sarhad Journal of Agriculture, 23(2), 293.

Babu RSH (2001). Limes and Lemons. In: Chadha, KL ed. Handbook of Horticulture. ICAR, New Delhi. 212.

Bae YS, Park K, Lee YG, Choi OH (2007) A simple and rapid method for functional analysis of plant growth promoting rhizobacteria using the development of cucumber adventitious root system. Plant Pathology Journal 23(3): 223-225.

Caesar AJ and Burn TJ (1987) Growth promoting of apple seedlings and rootstocks by specific strains of bacteria. Phytopathology 77: 15831588.

Datta, Chhaya and Basu, P. (2000). Indole acetic acid production by a Rhizobium species from root nodules of a leguminous shrub, Cajanus cajan. Microbiological research. 155. 123-7. 10.1016/S0944-5013(00)80047-6.

Davies, P.J. (Ed.) (2013). Plant hormones: physiology, biochemistry and molecular biology. Springer Science and Business Media.

Ercisli S, Esitken A, Sahin F (2004). Exogenous IBA and inoculation with Agrobacterium rubi stimulate adventitious root formation on 
hardwood stem cuttings of two rose genotypes. Hort Science 39 (3): 533534.

Esitken A, Ercisli S, Sevik I, Sahin F (2003). Effect of indole-3-butyric acid and different strains of Agrobacterium rubi on adventive root formation from softwood and semi-hardwood wild sour cherry cuttings. Turkish Journal of Agriculture and Forestry 27: 37-42.

Hartmann, H.T., Kester, D.E. and Davies, F.T., and J.R.(1990). Plant Propagation: Principles and Practices, 5th Edition, Prentice Hall International Editions. Englewood Cliffs, New Jersey, USA.

Kaymak, H. C., Yarali, F., Guvenc, I., and Donmez, M. F. (2008). The effect of inoculation with plant growth rhizobacteria (PGPR) on root formation of mint (Mentha piperita L.) cuttings. African journal of Biotechnology, 7(24).

Loper JE and Schroth MN (1986). Influence of bacterial source of indole-3acetic acid of root elongation of sugar beet. Phytopathol 76: 386-389.

Lynch JM (1985). Origin, nature and biological activity of aliphatic substances and growth hormones found in soil. In: Soil Organic Matter and Biological Activity. Eds. Vaughan D and Malcom RE. Martinus Nijhoff, Dr.
W. Junk Publishers. Dordrecht, Boston , Lancaster. pp 151-174

Mcafee BJ, White EE, Pelcher LE, Lapp MS (1993) Root induction in Pine (Pinus) and Larch (Larix) spp. using Agrobacterium rhizogenes. Plant Cell, Tissue and Organ Culture 34: 53-62.

Nanda, K. K. (1975). Physiology of adventitious root formation.

Patten CL and Glick BR (2002). Role of Pseudomonas putida indole acetic acid in development of the host plant root system. Applied Environmental Microbiology 68: 3795-3801.

Paul, R., and Aditi, C. (2009). IBA and NAA of $1000 \mathrm{ppm}$ induce more improved rooting characters in air-layers of waterapple (Syzygium javanica L.). Bulgarian Journal of Agricultural Science, 15(2), 123-128.

Rana, H. S., and Jindal, K. K. (2001). Effect of types of cutting and auxin treatment on the rooting of cuttings of some commercial kiwifruit cultivars. Haryana Journal of Horticultural Sciences, 30(1/2), 3-5.

Rathore, D.S. (1984). Propagation of chinese gooseberry from stem cuttings. Indian Journal of Horticulture, 41(3 and 4), 237-239.

\section{How to cite this article:}

Sabari Priya, V., C. Subesh Ranjith Kumar, R. Poorniammal, J. Rajangam and Venkatesan, K. 2020. Standardization of Propagation Technique and Media Combination in Acid Lime (Citrus aurantifolia) var. PKM 1. Int.J.Curr.Microbiol.App.Sci. 9(10): 2174-2184. doi: https://doi.org/10.20546/ijcmas.2020.910.264 